\title{
VARIABLE FREQUENCY DRIVE OF GRAIN MACHINE CONVEYOR WITH IMPROVED QUALITY INDICATORS
}

\section{S. Serhiienko, E. Burdilna}

Kremenchuk Mykhailo Ostrohradskyi National University

ORCID: 0000-0002-3977-5239; 0000-0002-4539-9655

\section{O. Klyuyev}

Dniprovsk State Technical University

ORCID: 0000-0003-4542-3317

Purpose. The article explored options for control systems for the electric drive of grain-metal machine conveyor to stabilize the speed of conveyor belt when the load changes. Methodology. A control system is proposed that implements the principles of subordinate regulation and is supplemented by compensatory feedbacks in the control channels of active and reactive energy. The calculation of the regulators and the modeling of the system operation have been completed. The analysis of the obtained characteristics showed that the synthesized system is characterized by good quality indicators. However, the characteristics were obtained for the case of known parameters of an asynchronous machine and adjusting the regulators for these parameters. Studies have shown that for the proposed structure, the most significant is the incorrect determination of the inductive reactances of the stator and rotor of asynchronous machine. So, when the inductance deviates by $30 \%$, significant fluctuations occur in the subordinate regulation system. Complex solution to the problem of providing low sensitivity to parametric and coordinate disturbances and an increase in dynamic and static accuracy can be obtained in a class of systems, that are stable with an unlimited increase in the gain, as a solution to the problem of analytical design of optimal regulators based on the modified symmetry principle. The regulators of the reactive energy transmission channel with series-parallel correction, which are modified PID structures, have been synthesized. Regulators with sequential correction with PID and PIDD ${ }^{2}$ structures are synthesized for the active energy transmission channel. Results. Analysis of the obtained results of characteristics showed, that the optimal control system is characterized by better quality indicators in comparison with the classical system of subordinate regulation and practically insensitive to changes in the parameters of the electric drive. Originality. The results of mathematical modeling confirmed the possibility of using control systems synthesized as a solution to the problem of analytical design of optimal controllers based on the modified symmetry principle, to improve the quality indicators of the AC electric drive of the grain thrower conveyor. Practical value. The use of the proposed optimal control system will provide the possibility of stabilizing the speed of the conveyor belt of the grain thrower, which will reduce the percentage of injured and damaged grain. References 16 . Figures 14.

Key words: variable frequency drive, regulator, rotor flux linkage, modeling, system of differential equations, subordinate regulation, quality indicators, analytical design of regulators, optimal control.

\section{ЧАСТОТНО-РЕГУЛЬОВАНИЙ ЕЛЕКТРОПРИВОД КОНВЕСРА ЗЕРНОМЕТАЛЬНОЇ МАШИНИ З ПОКРАЩЕНИМИ ЯКІСНИМИ ПОКАЗНИКАМИ}

\section{С. А. Сергіснко, С. В. Бурдільна}

Кременчуцький національний університет імені Михайла Остроградського

ORCID: 0000-0002-3977-5239; 0000-0002-4539-9655

О. В. Клюсв

Дніпровський державний технічний університет

ORCID: 0000-0003-4542-3317

Розглянуто систем керування електроприводом конвеєра зернометальної машини для стабілізації швидкості стрічки конвеєра при зміні навантаження. Синтезовано та досліджено роботу систему керування, яка реалізує принципи підпорядкованого регулювання та доповнена компенсаційними зворотними зв'язками в каналах управління активної і реактивної енергії. Аналіз результатів моделювання показав задовільні результати роботи системи, але лише для випадку відомих параметрів асинхронної машини і настройки регуляторів на ці параметри. 3 метою підвищення якісних показників досліджено систему синтезовану як рішення задачі аналітичного конструювання оптимальних регуляторів на основі модифікованого принципу симетрії. Отримані результати показали, що система оптимального керування характеризується кращими показниками якості в порівнянні з класичною системою підпорядкованого регулювання та практично не чутлива до змін параметрів електроприводу. Результати математичного моделювання підтвердили можливість застосування систем управління, синтезованих як рішення задачі аналітичного конструювання оптимальних регуляторів на основі модифікованого принципу симетрії для підвищення якісних показників електроприводу змінного струму конвеєра зернокидача. Застосування запропонованої системи оптимального керування забезпечить можливість стабілізації швидкості стрічки конвеєра зернометальника, що дозволить зменшити відсоток травмованого та пошкодженого зерна.

Ключові слова: частотно-регульований електропривод, регулятор, потокозчеплення ротора, моделювання, система диференційних рівнянь, підпорядковане регулювання, якісні показники, аналітичне конструювання регуляторів, оптимальне керування. 
PROBLEM STATEMENT. The role of the agricultural sector in the Ukrainian economy is one of the main. The possibilities of improving and increasing the efficiency of collection processes are widely considered or crop processing, at the same time the possibility of reducing losses and damage to products. Known negative impact of working elements of agricultural machinery on grain material during post-harvest processing, namely, injury and deformation of the weevil, which leads to a decrease in product quality, a decrease in sowing properties and shelf life, an increase in the development of pests, fungi, etc. Known ways to reduce the impact on the grain material are to change the mechanical part of the machines, involved in the stages of reloading, transportation, reloading [1-6]. The most common at this stage of post-harvest processing are ZM series grain throwers. The principle of operation of these machines is to collect grain from the floor with scrapers, then go to the conveyor belt, which moves at a constant speed (from 10 to $20 \mathrm{~m} / \mathrm{s}$ depending on a design) and further the grain stream under the action of force of inertia gets to a trench and is thrown out. The trajectory of movement is set by the guiding metal spout, striking into which the grain is injured and deformed.

In grain-metal machines of the ZM series, an asynchronous motor is installed in the basic design for the conveyor, which is unregulated. The task of optimizing the operation of grain-metal machines is the possibility of modernizing the electrical part by introducing a frequency-controlled electric drive of the conveyor to set the desired trajectory of the grain flow without using a guide spout.

The purpose of the work is to synthesize and study the optimal control system for the asynchronous electric drive of the grain thrower conveyor.

MATERIAL AND RESULTS. With the improvement of means of regulation and the reduction in the cost of converting equipment for mechanisms with high requirements for dynamic and static characteristics, there has been a tendency to expand the scope of application of AC electric drives based on frequency converters with vector control [7-10].

Asynchronous electric drive in the coordinate axes oriented on the vector of flux coupling of the rotor $\stackrel{1}{\Psi}_{r}$, can be represented in the orthogonal coordinate system by two systems of equations, each of which separately describes the channels for the transmission of active and reactive energies $[11,12]$ :

$$
\left\{\begin{array}{l}
p \Psi_{r u}=-\frac{\Psi_{r u}}{T_{r}}+\frac{L_{m}}{T_{r}} I_{s u}, \\
p I_{s u}=\frac{K_{r}}{T_{r} T_{l}^{\prime} R^{\prime}} \Psi_{r u}-\frac{I_{s u}}{T_{l}^{\prime}}+\frac{U_{s u}}{R T_{l}^{\prime}}, \\
p U_{s u}=-\frac{U_{s u}}{T_{c o n}}+\frac{K_{c o n}}{T_{c o n}} u_{y} .
\end{array}\right.
$$

$$
\left\{\begin{array}{l}
p \omega=\frac{3 N K_{r}}{2 J} \Psi_{r u} I_{s v} \\
p I_{s v}=-\frac{K_{r} \Psi_{r u}}{R T_{l}^{\prime}} \omega-\frac{1}{T_{l}^{\prime}} I_{s v}+\frac{1}{R T_{l}^{\prime}} U_{s v} \\
p U_{s v}=-\frac{U_{s v}}{T_{c o n}}+\frac{K_{c o n}}{T_{c o n}} u_{y}
\end{array}\right.
$$

where $L_{m}-$ mutual inductance of the rotor and stator phase (and vice versa), due to the total flux created by all stator windings;

$L_{s}^{\prime}-$ transient inductance;

$L_{s}^{\prime}=L_{s \sigma}+K_{r} L_{r \sigma}$;

$L_{s}, L_{r}-$ full inductors of the stator and rotor; $L_{s}=L_{m}+L_{s \sigma} ; L_{r}=L_{m}+L_{r \sigma} ;$

$L_{s \sigma}, L_{r \sigma}-$ the scattering inductance of the stator and rotor windings;

$K_{r}=\frac{L_{m}}{L_{r}} ; R^{\prime}=R_{s}+K_{r}^{2} R_{r} ; T_{l}^{\prime}=\frac{L_{s}^{\prime}}{R^{\prime}} ; T_{r}=\frac{L_{r}}{R_{r}} ;$

$T_{c o n}, K_{c o n}-$ time constant and gain of the frequency converter;

$N$ - the number of poles of the motor.

For the control object (1), (2) in [13], a control system was proposed that implements the principles of subordinate regulation and is supplemented by compensatory feedbacks in the control channels of active and reactive energy. The loop regulators of the active and reactive components of the current and the rotor flux linkage module were tuned to the modular optimum, and the speed loop to the symmetric optimum.

PI controller of the reactive component of the stator current has a transfer function:

$$
W_{\text {reg.c.r }}(p)=\frac{T_{l}^{\prime} R^{\prime}}{2 T_{c o n} K_{c o n} K_{r c}}+\frac{R^{\prime}}{2 T_{c o n} K_{c o n} K_{r c} p}
$$

and adjusts the internal current circuit to the modular optimum.

PI regulator of the active component of the stator current has the same transfer function only with a different current feedback factor.

$$
W_{\text {reg.c.a }}(p)=\frac{T_{l}^{\prime} R^{\prime}}{2 T_{c o n} K_{c o n} K_{a c}}+\frac{R^{\prime}}{2 T_{c o n} K_{c o n} K_{a c} p},
$$

where $K_{r c}, K_{a c}$ - reactive and active feedback coefficients, respectively.

The transfer function of the flow regulator will be:

$$
W_{\text {reg } \psi}(p)=\frac{T_{r} K_{r c}}{4 T_{c o n} L_{m} K_{\Psi}}+\frac{K_{r c}}{4 T_{c o n} L_{m} K_{\Psi} p},
$$

where $K_{\Psi}$ - flux coupling feedback factor.

All other parameters are known from the above. 
The transfer function of the speed controller has the form:

$$
W_{\text {reg } \omega}(p)=\frac{J K_{a c}}{4 T_{c o n} K K_{\omega}}+\frac{J K_{a c}}{32 T_{c o n}^{2} K K_{\omega} p},
$$

where $J$ - moment of inertia;

$K_{\omega}$ - speed feedback coefficient;

$K=\frac{3}{2} N K_{r} \Psi_{r u n}-$ the coefficient of proportionality between the active component of the stator current and the electromagnetic moment at constant current.

From the equations of the steady-state operation of an AM:

$$
\Psi_{\text {run }} \approx \frac{U_{m}}{\omega_{0}\left(\frac{L_{s}^{\prime}}{L_{m}}+K_{r}\right)},
$$

$\omega_{0}-$ field frequency in the machine gap, $\omega_{0}=157 \mathrm{rad} / \mathrm{sec}$;

$U_{m}$ - amplitude of phase supply voltage.

An asynchronous motor type was used to model the operating modes AИР132S6У2 with the parameters of the power unit, $P_{n}=5,5 \mathrm{~kW}, U_{f}=220 \mathrm{~V}, \eta=0,8$, $\cos \varphi=0,6 \quad, \quad R_{s}=0,067 \quad \mathrm{Ohm}, \quad R_{r}^{\prime}=0,11 \quad \mathrm{Ohm}$, $X_{s}=0,072$ r.u., $X_{r}^{\prime}=0,11$ r.u., $X_{\mu}=0,138$ r.u., $n_{n}=1000 \mathrm{rpm}, K_{c o n}=40, T_{c o n}=0,002 \mathrm{~s}$.

The simulation was carried out for starting at idle, surge and shedding of the rated load, and stopping the motor.

The simulation results (Fig. 1-3) confirm the efficiency of the proposed control system and high quality control indicators. So the speed adjustment does not exceed $5 \%$, the adjustment time is $0.4 \mathrm{~s}$, the dynamic speed drop when sketching the rated load is $2 \%$. Vector control system allows to reduce torque fluctuations during starting due to preliminary excitation of the motor and stabilization of the flux linkage at a nominal level in a minimum time. The maximum value of the moment does not exceed the allowable.

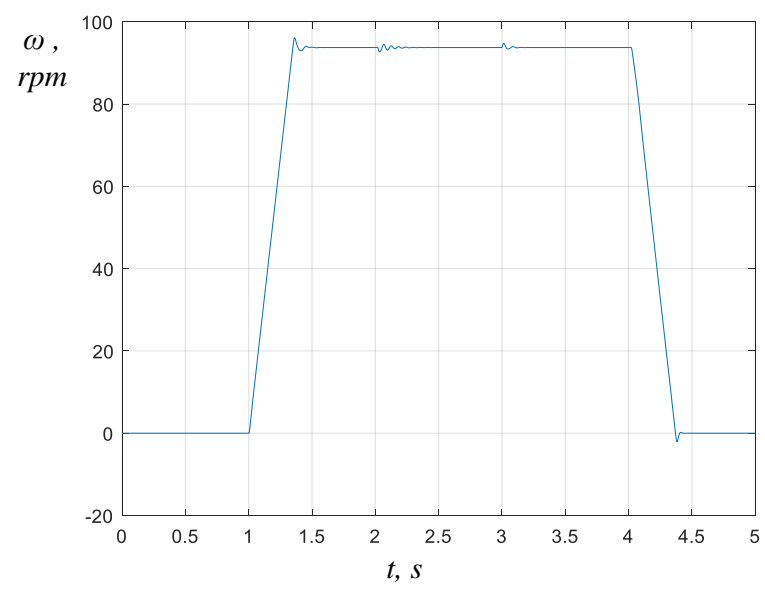

Figure 1 - Rotor speed

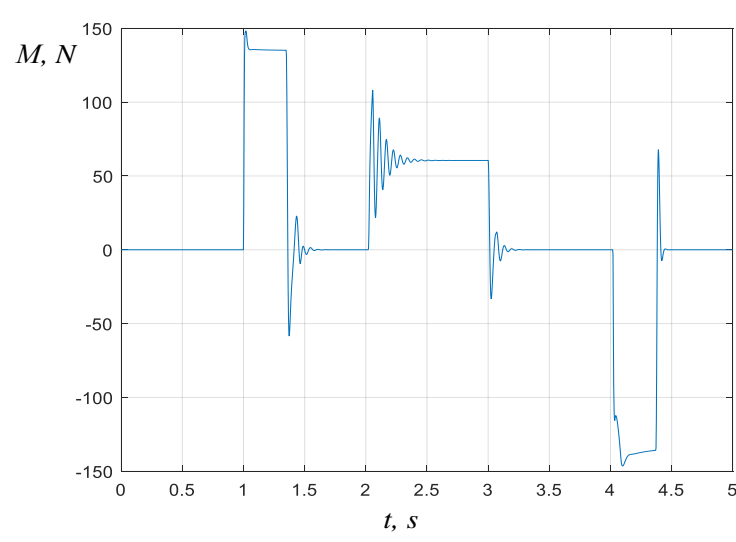

Figure 2 - Electromagnetic torque of the motor

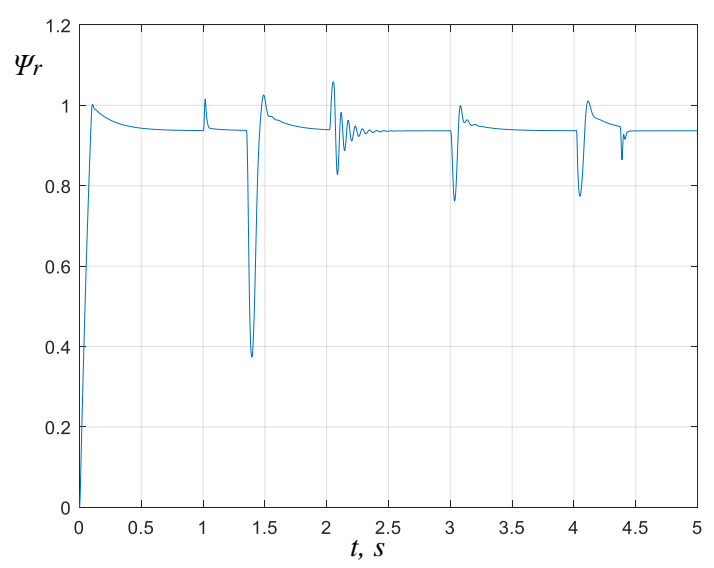

Figure 3 - Rotor flux linkage module

However, these characteristics were obtained for the case of known parameters of an asynchronous machine and adjusting the regulators for these parameters. It is known that even the values given in catalogs and directories are calculated and can differ significantly from the actual values of a particular machine. In addition, long-term operation, difficult working conditions, especially typical for agricultural machinery, constant change of climatic conditions, lead to the fact that the parameters of an asynchronous machine can change significantly. Engine repairs, acquired defects also lead to additional changes in the parameters of the AM and even to a change in the nominal slip. It is also known that the temperature drift of the values of the active resistances of the AM (reaching in practice one and a half times of their nominal value and is caused by a change in the load mode of the drive or by varying the ambient temperature) introduces a significant error in the identification of these resistances and leads, in turn, to a deterioration in the accuracy of flux linkage control and engine speed [14].

Inconsistency of the settings with the actual values of the parameters of the frequency-controlled asynchronous electric drive can lead to a significant decrease in the dynamic quality indicators or even to the complete inoperability of the electromechanical system.

Studies have shown that for the proposed structure, the most significant is the incorrect determination of the inductive reactances of the stator and rotor of the AM. So, when the inductance deviates by $30 \%$, significant fluctuations occur in the slave control system (Fig. 4-6), and 
for certain combinations of parameters, the system can generally become unstable.

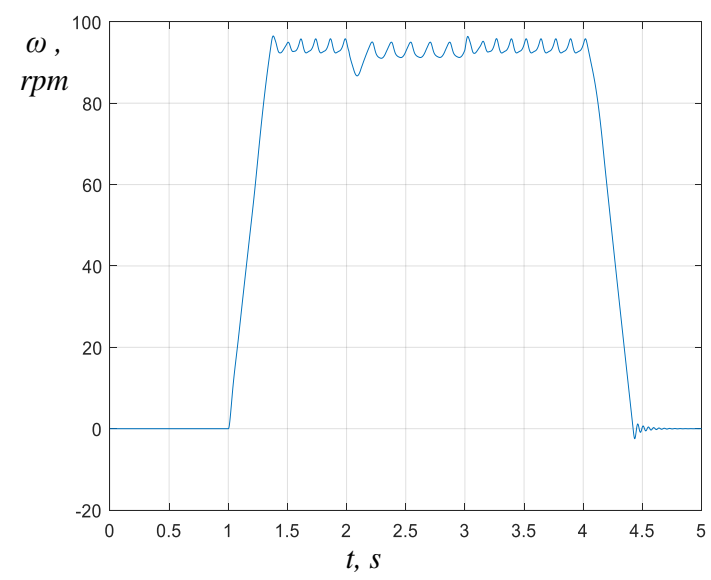

Figure 4 - Rotor speed

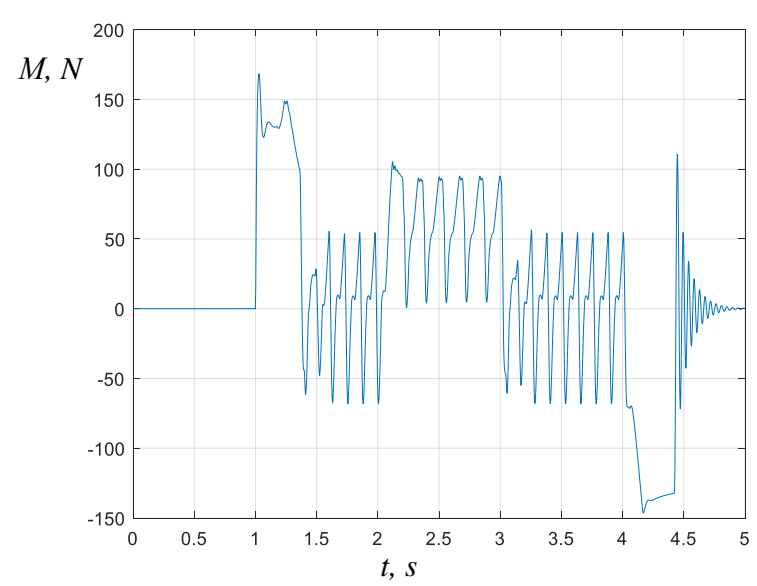

Figure 5 - Electromagnetic torque of the motor

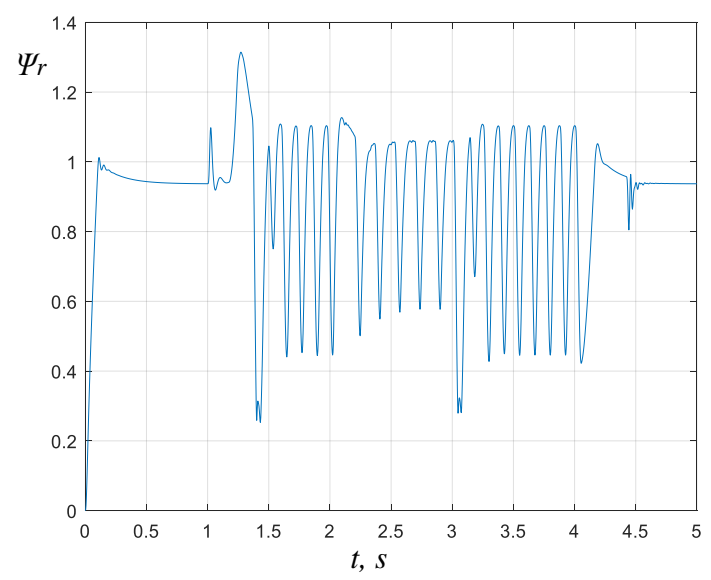

Figure 6 - Rotor flux linkage module

High sensitivity to changes in the parameters of the power unit of the electric drive is a consequence of the low gains of the loop controllers, which are inversely proportional to the gains of the corresponding control objects when optimizing the contours both in terms of modular and symmetric optima.

A comprehensive solution to the problem of providing low sensitivity to parametric and coordinate pertur- bations, as well as increasing the dynamic and static accuracy can be obtained in the class of systems that are stable with an unlimited increase in the gain $[15,16]$ as a solution to the problem of analytical design of optimal controllers based on the modified symmetry principle.

We introduce new variables and write system (1) as follows:

$$
\left\{\begin{array}{l}
p y_{1 r}=b_{11} y_{1 r}+b_{12} y_{2 r}, \\
p y_{2 r}=b_{21} y_{1 r}+b_{22} y_{2 r}+b_{23} y_{3 r}, \\
p y_{3 r}=b_{33} y_{3 r}+m_{3} u_{y r},
\end{array}\right.
$$

where $y_{1 r}=\Psi_{r u} ; y_{2 r}=I_{s u} ; y_{3 r}=U_{s u}$;

$b_{11}=-\frac{1}{T_{r}} ; b_{12}=\frac{L_{m}}{T_{r}} ; b_{21}=\frac{K_{r}}{T_{r} T_{l}^{\prime} R^{\prime}} ; b_{22}=-\frac{1}{T_{l}^{\prime}} ;$

$b_{23}=\frac{1}{T_{l}^{\prime} R^{\prime}} ; b_{33}=-\frac{1}{T_{c o n}} ; m_{3}=\frac{K_{c o n}}{T_{c o n}}$.

Let us write the system of differential equations in deviations:

$$
\left\{\begin{array}{l}
p \eta_{1 r}=b_{11} \eta_{1 r}+b_{12} \eta_{2 r}, \\
p \eta_{2 r}=b_{21} \eta_{1 r}+b_{22} \eta_{2 r}+b_{23} \eta_{3 r} \\
p \eta_{3 r}=b_{33} \eta_{3 r}+m_{3} U_{r}
\end{array}\right.
$$

where $\eta_{k r}(t)=y_{k r}(t)-y_{k r}^{*}(t)-$ deviation of the real movement from the desired, $U_{r}=u_{y r}-u_{r}^{*}-$ additional control, which is a deviation of the actual control $u_{y r}$ from the software $u_{r}^{*}$ and is designed to compensate for all external disturbances in order to combine real movement with the desired.

According to the method described in [16], we will synthesize the regulators of the reactive energy transmission channel.

Optimal control $U_{2 r}\left(\eta_{1}, \eta_{2}, \eta_{3}\right)$ of the stator current component regulator $I_{s u}$ on the trajectories of the system (8) in the presence of a restriction on the maximum value of the control effect is defined as

$$
U_{2 r}=-s a t\left[\frac{g_{2 r}}{m_{3}}\left(\frac{v_{03}}{p} \eta_{2 r}+v_{13} \eta_{1 r}+v_{23} \eta_{2 r}+v_{33} \eta_{3 r}\right)\right]
$$

where $v_{i 3},(i=0, \ldots, 3)$ - the coefficients of the Lyapunov function at $n=3$, which are calculated from the determinant of the coefficients of the system (6)

and are equal

$$
\Delta=\left|\begin{array}{ccc}
b_{11} & b_{12} & 0 \\
b_{21} & b_{22} & b_{23} \\
0 & 0 & b_{33}
\end{array}\right|
$$

$$
\begin{aligned}
& v_{03}=-b_{33}\left(b_{11} b_{22}-b_{12} b_{21}\right) ; v_{13}=-b_{21} b_{33} ; \\
& v_{23}=b_{11} b_{33} ; v_{33}=-b_{11} b_{23} .
\end{aligned}
$$

Expressing from the second equation of the system (8) $\eta_{3 r}$ in terms of other coordinates of the disturbed motion, 
taking into account the values of the coefficients (10), after mathematical transformations we obtain the following form of optimal control for the phase space of the disturbed motion:

$U_{2 r}=-s a t\left[\left(\frac{\vartheta_{20}}{p}+\vartheta_{22}+\vartheta_{23} p\right) \eta_{2 r}+\vartheta_{21} \eta_{1 r}\right]$

where

$$
\vartheta_{20}=\frac{g_{2 r}\left(-b_{33}\right)\left(b_{11} b_{22}-b_{12} b_{21}\right)}{m_{3}} ;
$$

$\vartheta_{21}=\frac{g_{2 r} b_{21}\left(b_{11}-b_{33}\right)}{m_{3}} ;$

$$
\vartheta_{22}=\frac{g_{2 r} b_{11}\left(b_{22}+b_{33}\right)}{m_{3}} ; \vartheta_{23}=\frac{g_{2 r}\left(-b_{11}\right)}{m_{3}} ;
$$

$g_{2 r}$ - the gain of the open circuit of the stator current component $I_{s u}$.

To determine the optimal control of the stabilization loop of the rotor flux linkage, we substitute the control action (11) into the last equation of system (8) without taking into account the integral component:

$$
\left\{\begin{array}{l}
p \eta_{1 r}=b_{11} \eta_{1 r}+b_{12} \eta_{2 r}, \\
p \eta_{2 r}=b_{21} \eta_{1 r}+b_{22} \eta_{2 r}+b_{23} \eta_{3 r}, \\
p \eta_{3 r}=b_{1} \eta_{1 r}+b_{2} \eta_{2 r}+b_{3} \eta_{3 r}+U_{1},
\end{array}\right.
$$

where

$b_{1}=-g_{2 r} b_{21} b_{33} ; \quad b_{2}=g_{2 r} b_{11} b_{33} ; b_{3}=b_{33}-g_{2 r} b_{11} b_{23}$.

Control action of the rotor flux linkage regulator $U_{1 \psi}$ is determined similarly to the calculation given for the circuit of the stator current component $I_{s u}$ :

$$
U_{1 \psi}=-s a t\left[\left(\frac{\vartheta_{10}}{p}+\vartheta_{11}+\vartheta_{12} p\right) \eta_{1 r}+\vartheta_{13} p \eta_{2 r}\right],
$$

where

$$
\begin{gathered}
\vartheta_{10}=g_{1 \psi}\left[b_{11}\left(b_{22} b_{3}-b_{23} b_{2}\right)-b_{12}\left(b_{21} b_{3}-b_{23} b_{1}\right)\right] ; \\
\vartheta_{11}=g_{1 \psi}\left(b_{22} b_{3}-b_{23} b_{2}-b_{12} b_{21}\right) ; \\
\vartheta_{12}=g_{1 \psi}\left(-b_{3}-b_{22}\right) ; \vartheta_{13}=g_{1 \psi} b_{12} ;
\end{gathered}
$$

$g_{1 \psi}$ - the gain of the open loop control circuit of the rotor.

Algorithms (11), (13) can be implemented in a system with mixed serial-parallel correction. The block diagram corresponding to the found control algorithms is presented in Fig. 7.

Let us present the system of equations (2) with stabilization of the rotor flux linkage at the level of the nominal value:

$$
\left\{\begin{array}{l}
p y_{1 a}=n_{12} y_{2 a}, \\
p y_{2 a}=n_{21} y_{1 a}+n_{22} y_{2 a}+n_{23} y_{3 a}, \\
p y_{3 a}=n_{33} y_{3 a}+m_{3} u_{y a},
\end{array}\right.
$$

where $y_{1 a}=\omega ; y_{2 a}=I_{s v} ; y_{3 a}=U_{s v}$

$$
\begin{aligned}
& n_{12}=\frac{3 N^{2} K_{r}}{2 J} \Psi_{\text {run }} ; n_{21}=-\frac{K_{r}}{R T_{l}^{\prime}} \Psi_{\text {run }} ; n_{22}=-\frac{1}{T_{l}^{\prime}} ; \\
& n_{23}=\frac{1}{R^{\prime} T_{l}^{\prime}} ; n_{33}=-\frac{1}{T_{\text {con }}} ; m_{3}=\frac{1}{T_{\text {con }}} ;
\end{aligned}
$$

The system of differential equations in deviations will look like:

$$
\left\{\begin{array}{l}
p \eta_{1 a}=n_{12} \eta_{2 a}, \\
p \eta_{2 a}=n_{21} \eta_{1 a}+n_{22} \eta_{2 a}+n_{23} \eta_{3 a} \\
p \eta_{3 a}=n_{33} \eta_{3 a}+m_{3} U_{a} .
\end{array}\right.
$$

Optimal control $U_{2 a}\left(\eta_{1}, \eta_{2}, \eta_{3}\right)$ of the stator current component regulator $I_{s v}$ if there is a restriction on the maximum value of the control effect should be sought in the form:

$$
\begin{gathered}
U_{2 a}=-s a t\left[\frac{g_{2 a}}{M_{3}}\left(v_{03} \eta_{0}+v_{13} \eta_{1}+v_{23} \eta_{2}+v_{33} \eta_{3}\right)\right] ; \\
U_{2 a}=-s a t\left[\frac{g_{2 a}}{M_{3}}\left(\frac{v_{03}}{p^{2}}+\frac{v_{13}}{p}+v_{23}+v_{33} p\right) \eta_{2}\right] ;
\end{gathered}
$$

where $g_{2 a}$ - the gain of the open control circuit of the stator current component $I_{s v} ; v_{i 3},(i=0, \ldots, 3)-$ the coefficients of the Lyapunov function for $n=3$, which are defined as

$\hat{v}_{03}=a_{1}, \hat{v}_{13}=a_{2}, \hat{v}_{23}=a_{3}, \hat{v}_{33}=1$.

$a_{1}=n_{12} n_{21} n_{33} ; a_{2}=n_{22} n_{33}-n_{12} n_{21} ; a_{3}=-n_{22}-n_{33}$;

$M_{3}=m_{3} n_{23}$.

The component characterizing double integration can be omitted from the control law for $\hat{g}_{2 a} \rightarrow \infty$. Then the algorithm for optimal control of the stator current component $I_{s v}$ in the function of the control error will be written as:

$$
U_{2 a}=-s a t\left[\left(\frac{\tilde{\alpha}_{21}}{p}+\tilde{\alpha}_{22}+\tilde{\alpha}_{23} p\right) \eta_{2 a}\right],
$$

where

$$
\begin{gathered}
\tilde{\alpha}_{21}=\frac{\hat{g}_{2 a}\left(n_{22} n_{33}-n_{12} n_{21}\right)}{m_{3} n_{23}} ; \\
\& q_{22}=\frac{\hat{g}_{2 a}\left(-n_{22}-n_{33}\right)}{m_{3} n_{23}} ; \theta c_{23}=\frac{\hat{g}_{2 a}}{m_{3} n_{23}} .
\end{gathered}
$$

Similarly, the algorithm for optimal speed control as a function of control error is determined:

$$
U_{1 \omega}=-s a t\left[\left(\frac{\tilde{\alpha}_{10}}{p}+\tilde{\alpha}_{11}+\tilde{\alpha}_{12} p+\tilde{\alpha}_{13} p^{2}\right) \eta_{1 a}\right],
$$

$$
\begin{aligned}
& \text { where } \quad \tilde{\alpha}_{10}=g_{1 a} n_{12}\left(n_{21} n_{3}-n_{23} n_{1}\right) \\
& \tilde{\alpha}_{11}=g_{1 a}\left(n_{22} n_{3}-n_{23} n_{2}-n_{12} n_{21}\right) ; \\
& \tilde{\alpha}_{12}=g_{1 a}\left(-n_{22}-n_{3}\right) ; \tilde{\alpha}_{13}=\hat{g}_{1 a} ; \\
& n_{1}=-\frac{g_{2 a} n_{22} n_{33}}{n_{23} n_{12}} ; n_{2}=\frac{g_{2 a} n_{33}}{n_{23}} ; n_{3}=n_{33}-g_{2 a} ;
\end{aligned}
$$


$g_{1 a}-$ the gain of the open loop speed control.
Algorithms (17), (18) are implemented in a system with sequential correction, the block diagram of which is presented in Fig. 8.

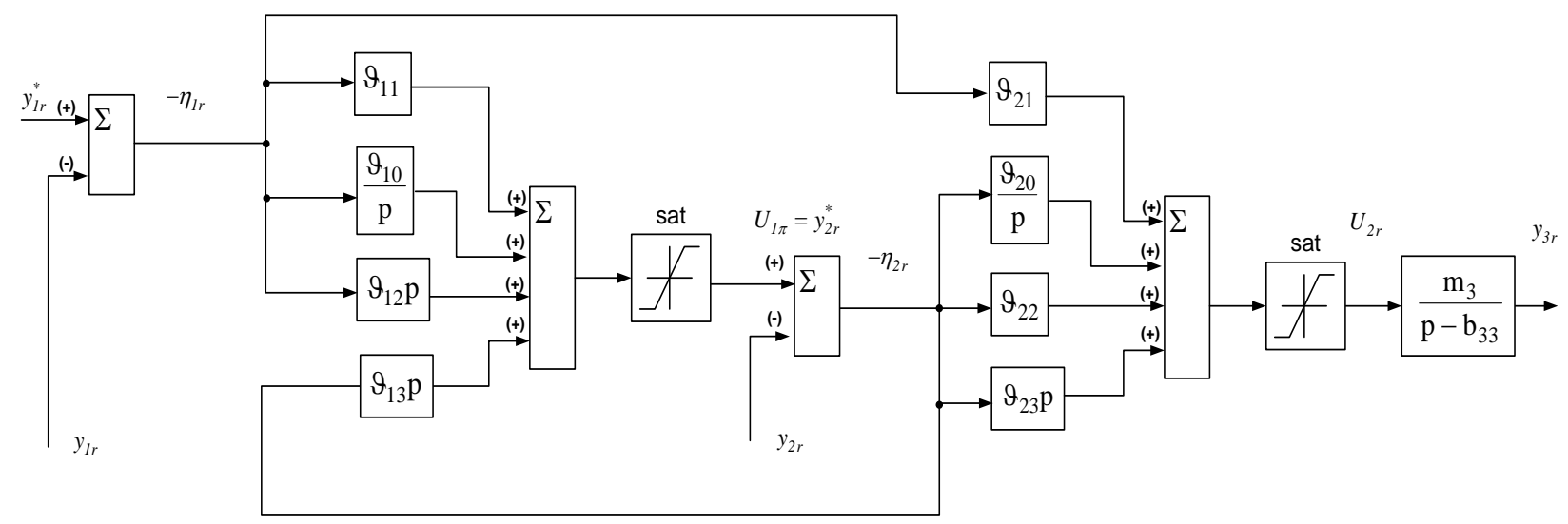

Figure 7 - Block diagram of control algorithms (9), (11)

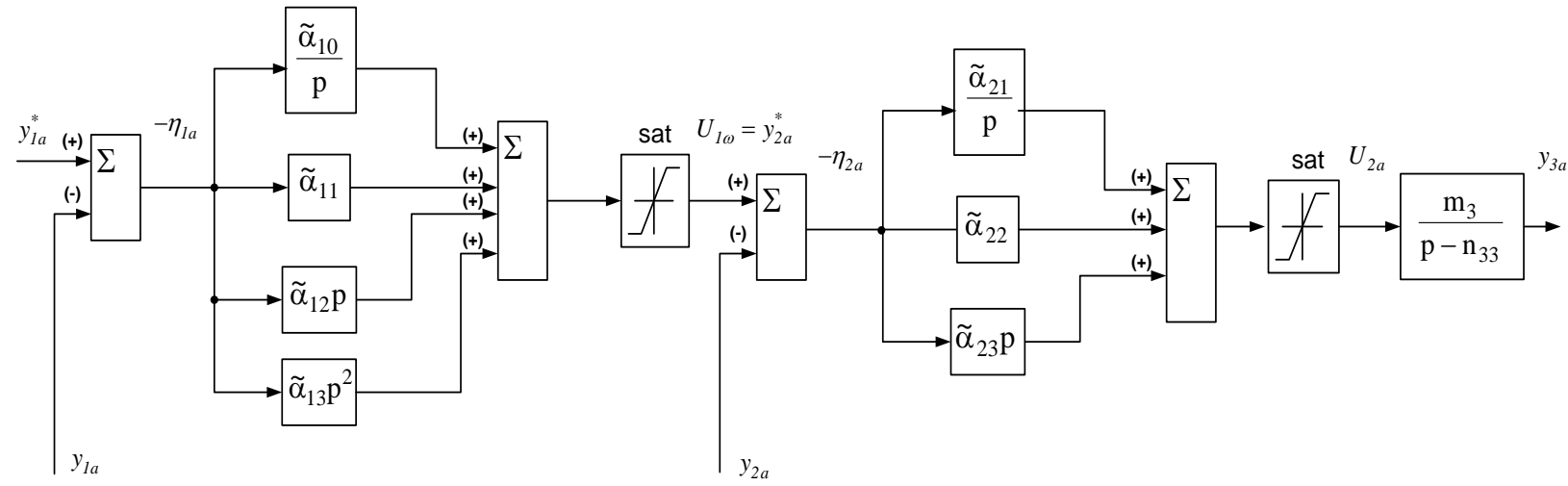

Figure 8 - Block diagram of control algorithms (13), (14)

The results of mathematical modeling of the optimal control system with algorithms (11), (13) and (17), (18) are shown in Fig. 9-11. The values of the gain of the loop controllers are taken as follows

$\left(k_{\text {reg.c.r }}=\vartheta_{22}=500 \quad, \quad k_{\text {reg.c.a }}=\tilde{\alpha}_{22}=500 \quad\right.$,

$\left.k_{\psi}=\vartheta_{11}=100, k_{\omega}=\tilde{\delta}_{11}=100\right)$.

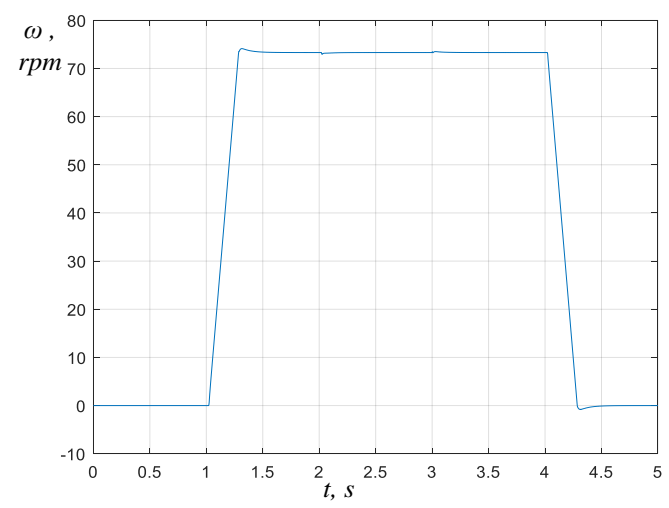

Figure 9 - Rotor speed

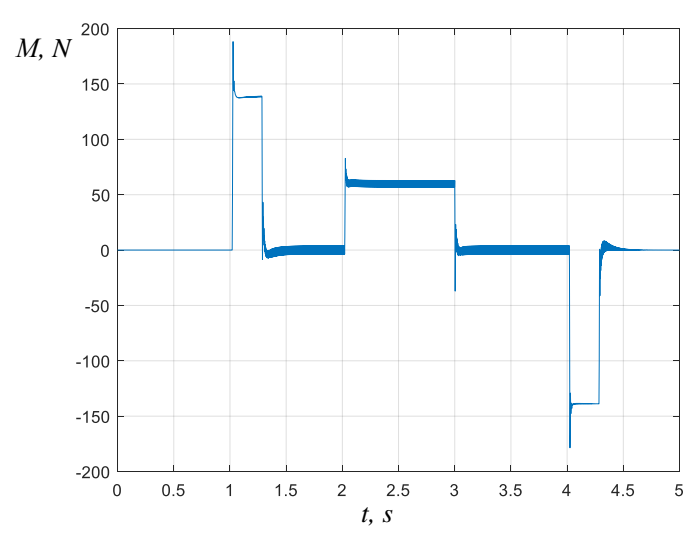

Figure 10 - Electromagnetic torque of the motor 


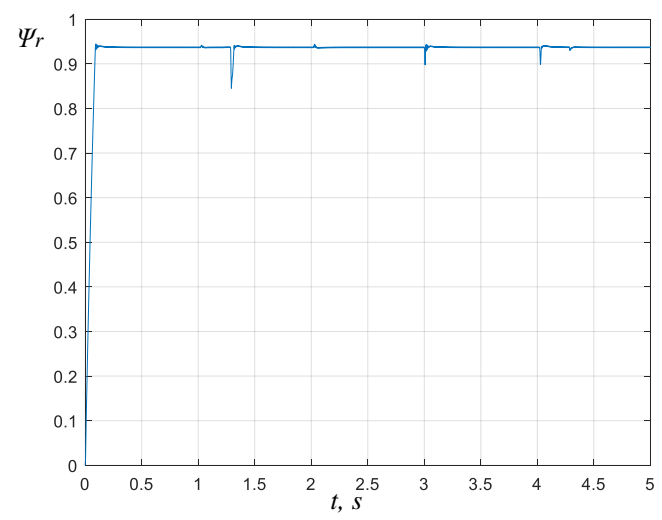

Figure 11 - Rotor flux linkage module

The analysis of transient characteristics shows that the optimal control system is characterized by better quality indicators in comparison with the classical system of subordinate regulation. So, when starting at idle, the overshoot is less than $2 \%$, and the astatic drop in speed when the rated load is set $-0,5 \%$. The absence of a static drop in the stator current and complete stabilization of the flux linkage leads to the absence of a static drop in the electromagnetic torque of the motor and, as a consequence, to a halving of the regulation time.

It is characteristic that the optimal control system is practically insensitive to changes in the parameters of the electric drive (Fig. 12-14).

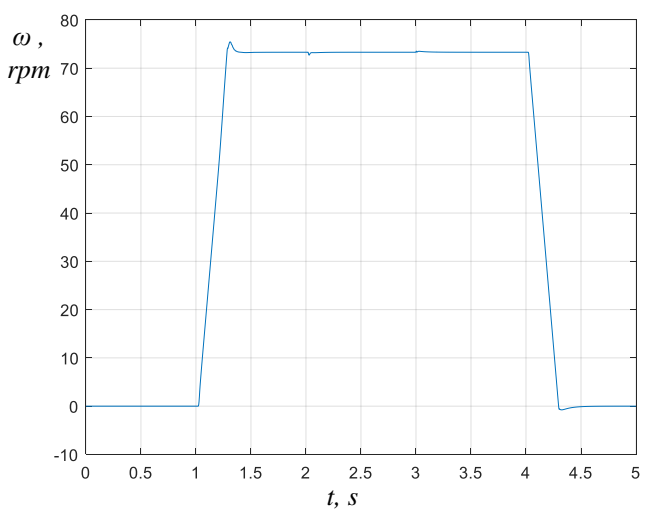

Figure 12 - Rotor speed

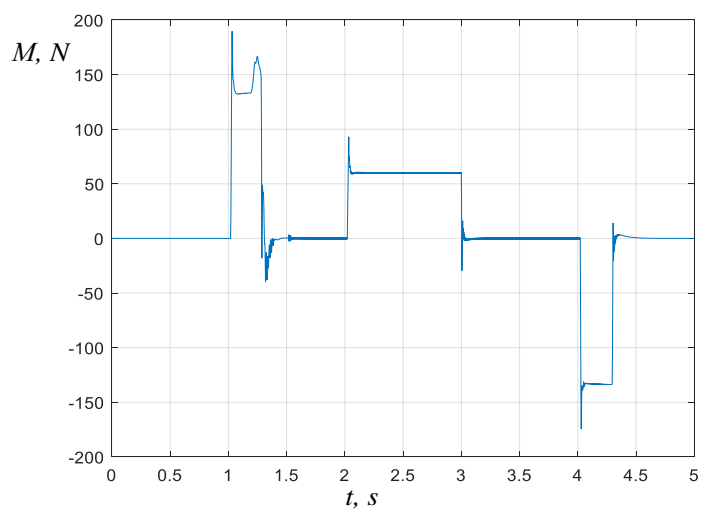

Figure 13 - Electromagnetic torque of the motor

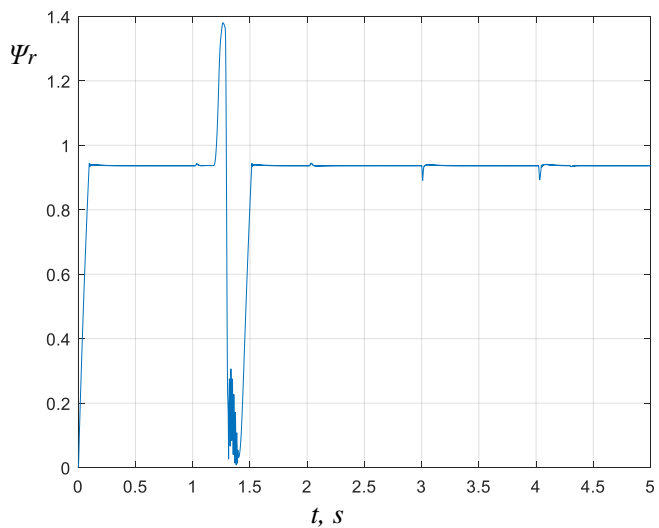

Figure 14 - Rotor flux linkage module

Thus, a doubling of the inductive resistances of the rotor and stator leads to a slight (up to $1 \%$ ) increase in overshoot and dynamic fluctuations in speed when the load changes. A significant change in the rotor flux linkage module when voltage is applied to the active energy transmission channel of the vector control system is compensated by the regulator in less than $0.2 \mathrm{~s}$. At the same time, the quality indicators of the optimal control system, even with not precisely defined parameters, are better than in the basic system of subordinate regulation.

CONCLUSIONS. The results of mathematical modeling confirmed the possibility of using control systems synthesized as a solution to the problem of analytical design of optimal controllers based on the modified principle of symmetry, to improve the quality of the AC drive of the conveyor of the grain thrower.

In the system of optimal control without loss of stability due to high values of the gains of loop controllers, the influence of destabilizing factors practically does not affect the quality indicators of control processes and ensure low sensitivity to parametric and coordinate disturbances.

\section{REFERENCES}

1. Tarasenko, A. P., Orobinskiy, V. I., Gievskiy, A. M., Baskakov, I. V., Chernyshov, A. V., Kharitonov, M. K. (2019), Snizhenie travmirovaniya zerna pri posleuborochnoy obrabotke [Reducing grain trauma during post-harvest processing]. Don Agrarian Science Bulletin. Vol. 1 (45), pp. 63-68. [in Russian]

2. Pascoe, R. D., Fitzpatrick, R., Garratt, J. R. (2015), Pradiction of automated sorter performance utilising a Monte Carlo simulation of feed characteristics. Minerals Engineering. Vol. 72, pp. 101-107.

3. Shukhanov, S. N., Rykov, I. G. (2011), Sovershenstvovanie tekhnicheskikh sredstv dlya metaniya zerna [Improvement of technical means for throwing grain]. Tractors and agricultural machines. Iss. 4, pp. 17-19. [in Russian]

4. Opalko, V., Shatrov, R., Shish, A., Marchenko, V. (2017), Mekhanichne travmuvannya zerna pislya zbirannya [Mechanical trauma of grain for picking]. Agroexpert. Iss. 2. [in Ukrainian]

5. Esin, K., Bodrov, A., Lomakin, D., Kulev, M. (2020), Reduction of Grain Loss During Harvesting Due 
to the Rational Distribution of Vehicles. MATEC Web of Conferences 334(51):02025.

DOI: $10.1051 /$ matecconf/202133402025

6. Gorbachev, I. V., Shukhanov, S. N. (2012), Travmiruemost' zerna kak vazhnyy pokazatel' kachestva raboty zernometatelya [Grain injury as an important indicator of the quality of the grain thrower]. Agrarian science. Iss. 1, pp. 26-27. [in Russian]

7. Wu, B., Mehdi, N. (2017), Other Multilevel Voltage Source Inverters. Wiley-IEEE Press, pp. 185-223.

8. Bouchiker, S., Capolino, G.-A., Poloujadoff, M. (1998), Vector control of a permanent-magnet synchronous motor using AC-AC matrix converter. IEEE Transactions on Power Electronics, 13, 6, pp. 1089-1099. DOI: 10.1109/63.728336.

9. Yerraguntla, Shasi Kumar, Gautam, Poddar (2018), Medium-Voltage Vector Control Induction Motor Drive at Zero Frequency Using Modular Multilevel Converter. IEEE Transactions on Industrial Electronics, $65, \quad 1, \quad$ pp. 125-132. DOI: 10.1109/TIE.2017.2721927.

10. Vijayagopal, M., Silva, C., Empringham, L., Lillo, L. (2019), Direct Predictive Current-Error Vector Control for a Direct Matrix Converter. IEEE Transactions on Power Electronics, 34, 2, pp. 1925-1935. DOI: 10.1109/TPEL.2018.2833495.

11. Slezhanovskiy, O. V., Datskovskiy, L. Kh., Kuznetsov, I. S. (1983), Sistemy podchinennogo regulirovaniya elektroprivodov peremennogo toka $\mathrm{s}$ ven- til'nymi preobrazovatelyami [Systems of subordinate regulation of $\mathrm{AC}$ electric drives with valve converters]. Moscow, 256 p. [in Russian]

12. Rudakov, V. V., Stolyarov, I. M., Dartau, V. A. (1987), Asinkhronnye elektroprivody s vektornym upravleniem [Asynchronous electric drives with vector control]. Leningrad, 136 p. [in Russian]

13. Burdilna, E. V., Serhiienko, S. A., Chornyi, O. P. (2021). Sistema vektornogo keruvannya elektroprivodom konveera zernometal'noi mashini [Vector control system of electric drive of grain machine conveyor]. Electrical engineering and electrical energy. Iss. 2, pp. 8-16.[in Ukrainian]

14. Beshta, A. S., Balakhontsev, A. V., Khudoy, E. G. (2005), Identifikatsiya koordinat asinkhronnogo dvigatelya $\mathrm{v}$ usloviyakh dreyfa aktivnykh soprotivleniy [Identification of coordinates of an asynchronous motor under conditions of active resistance drift]. Electrical engineering and electrical energy. Iss. 2, pp. 52-64. [in Russian]

15. Meerov, M. V. (1967), Sintez struktur sistem avtomaticheskogo regulirovaniya vysokoy tochnosti [Synthesis of structures of high-precision automatic control systems]. Moscow, 424 p. [in Russian]

16. Sadovoy, A. V., Sukhinin, B. V., Sokhina, Yu. V. (1996), Sistemy optimal'nogo upravleniya pretsizionnymi elektroprivodami [Optimal control systems for precision electric drives]. Kyiv, 298 p. [in Russian] 